\title{
Formulation Development \& Evaluation of Buffered Tablet of Proton Pump Inhibitors Drug Rabeprazole Sodium
}

\author{
Mamta Kumari*, Dr. Nishi Prakash Jain \\ *Sagar Institute of Research \& Technology- Pharmacy, Bhopal, Madhya Pradesh 462041
}

\begin{abstract}
The aim of present study was to prepare buffered tablets of acid labile drug, Rabeprazole sodium for oral administration using buffering agents to protect a drug from gastric fluid. Rabeprazole belongs to a class of antisecretory compounds (substituted benzimidazole proton-pump inhibitors) that do not exhibit anticholinergic or histamine $\mathrm{H}_{2}$-receptor antagonist properties, but suppress gastric acid secretion by inhibiting the gastric $\mathrm{H}+, \mathrm{K}+\mathrm{ATPase}$ at the secretory surface of the gastric parietal cell. Rabeprazole blocks the final step of gastric acid secretion. The tablets were prepared by direct compression and wet granulation method. The formulations contain water soluble buffers such as sodium bicarbonate and trisodium phosphate as well as water insoluble buffers as magnesium oxide, magnesium hydroxide and calcium carbonate and crospovidone as superdisintegrant. Preformulation studies like angle of repose, bulk density, tapped density, Carr's index, hausner's ratios, DSC and drug/excipient compatibility study were conducted and evaluated for hardness, friability, weight variation, drug content, disintegration and in-vitro dissolution. In the present study, $\mathrm{pH}$ of $\mathrm{F} 6$ batch was found to be optimum and disintegration time is 42 sec. The drug release was found to show maximum drug release in case of F6 with $99.3 \%$ in 60 minutes. In case of stability studies study of the optimized batch, all the results were found to be satisfactory and within limits. There were no significant changes after the period of 1 month study.
\end{abstract}

Keywords: Rabeprazole sodium, Proton-pump inhibitors, Buffered tablet, Superdisintegrants, Buffering agents

Article Info: Received 08 June 2019; $\quad$ Review Completed 22 July 2019; $\quad$ Accepted 26 July 2019; Available online 15 August 2019

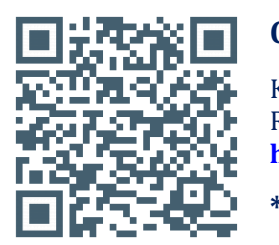

\section{Cite this article as:}

Kumari M, Jain NP, Formulation Development \& Evaluation of Buffered Tablet of Proton Pump Inhibitors Drug Rabeprazole Sodium , Journal of Drug Delivery and Therapeutics. 2019; 9(4-s):315-321

http://dx.doi.org/10.22270/jddt.v9i4-s.3324

Miss Mamta Kumari, Sagar Institute of Research \& Technology, Pharmacy, Bhopal, Madhya Pradesh 462041

\section{INTRODUCTION}

Rabeprazole sodium drug is a sodium salt of 2-(c4-(3methoxypropoxy)-3-methylpyridin-2-yl) methylsulfinyl)-1Hbenzo[d]imidazole belongs to a class of proton pump inhibitors. It suppress gastric acid secretion by specifically inhibiting the $\mathrm{H}^{+} / \mathrm{K}^{+}$- ATPase enzyme system at the secretory surface of the gastric parietal cell ${ }^{1}$. Peptic ulcer disease comprises a group of chronic ulcerative conditions that primarily affect the gastric mucosa and proximal duodenum. The drug like $\mathrm{H}_{2}$ blockers cimetidine, ranitidine and famotidine reduce the amount of acid produced by stomach. But Proton Pump Inhibitors (PPIs) are a group of drugs whose main action is pronounced and long-lasting reduction of gastric acid production. These drugs are metabolized in the parietal cells to active sulfonamide metabolites that inactivate the sulfhydryl group of the proton pump, thus reducing the hydrogen ion secretion 2,3 . Most of the PPIs are formulated in an enteric-coated solid dosage form (either a delayed-release capsule or tablet) or as an intravenous solution. There are some problems associated with entericcoated preparations as dissolution of the enteric coating is $\mathrm{pH}$-dependent and gastric empting time. $\mathrm{pH}$ profile of the gastrointestinal tract in an individual is variable at different times and is dependent on numerous physiological factors (e.g., the fed or fasted state), variable dissolution times for the enteric coat and variable pharmacokinetic profiles of individuals may affects ${ }^{4-6}$. The acid-labile drugs for oral administration may also be protected from gastric acidity by neutralizing the $\mathrm{pH}$ of the gastric fluid. So the current frontier in PPI therapy is immediate-release tablet combined with buffering agents which prevent degradation of drug by neutralizing the $\mathrm{pH}$ of stomach before absorption and protect the drug from low $\mathrm{pH}$. Such dosage forms are known as buffered tablet and such tablet is advantageously devoid of any enteric coating or delayed or sustained-release delivery ${ }^{7,8}$.

\section{MATERIAL AND METHOD}

\section{Material}

Rabeprazole sodium was obtained as gift sample from Cadila Healthcare Ltd., Ahmedabad. All chemicals were used of pharmaceutical grade obtained as gift sample from apex pharmaceutical, Chennai. 
Method

\section{Preformulation study}

\section{Melting point determination}

Melting point of Rabeprazole was determined by open capillary method.

\section{Determination of partition coefficient}

$25 \mathrm{mg}$ of drug was taken in three separating funnels. The separating funnels were shaken for $2 \mathrm{hrs}$ in a wrist action shaker for equilibration. Two phases were separated and the amount of the drug in aqueous phase was analyzed spectrophotometrically. The partition coefficient of the drug in phases was calculated by using formula.

\section{Determination of $\lambda$ max}

A solution of rabeprazole containing the concentration $10 \mu \mathrm{g} / \mathrm{ml}$ was prepared in $0.1 \mathrm{M} \mathrm{HCL}$ and UV spectrum was taken using Shimadzu (UV-1800) double beam spectrophotometer. The solution was scanned in the range of 200- $400 \mathrm{~nm}$

\section{Drug - excipient interaction studies by FTIR}

Infra-red spectra matching approach was used for the detection of any possible chemical reaction between the drug and the excipients. A physical mixture (1:1) of drug and excipients was prepared and mixed with suitable quantity of potassium bromide. About $100 \mathrm{mg}$ of this mixture was compressed to form a transparent pellet using a hydraulic press at 10 tones pressure. It was scanned from 4000 to 150 cm-1 in a shimadzu FTIR spectrophotometer. The IR spectrum of the physical mixture was compared with those of pure drug and excipients and matching was done to detect any appearance or disappearance of peaks.

\section{Preparation of standard calibration curve of rabeprazole sodium in 0.1M HCL}

$100 \mathrm{mg}$ of drug was accurately weighed and dissolved in $100 \mathrm{ml} 0.1 \mathrm{~N} \mathrm{HCl}$ in $100 \mathrm{ml}$ volumetric flask, to make $(1000 \mu \mathrm{g} / \mathrm{ml})$ standard stock solution (1). Then $10 \mathrm{ml}$ stock solution (1) was taken in another $100 \mathrm{ml}$ volumetric flask to make $(100 \mu \mathrm{g} / \mathrm{ml})$ standard stock solution (2), then again 0.5 , $1,1.5,2,2.5$ and $3 \mathrm{ml}$ of stock solution (2) was taken in another $10 \mathrm{ml}$ volumetric flask and then final concentrations were prepared $5,10,15,20,25$ and $30 \mu \mathrm{g} / \mathrm{ml}$ with $0.1 \mathrm{~N} \mathrm{HCl}$. The absorbance of standard solution was determined using UV/VIS spectrophotometer (Shimdzu Jappan) at 275.43nm. Linearity of standard curve was assessed from the square of correlation coefficient $\left(\mathrm{r}^{2}\right)$ which determined by least-square linear regression analysis.

Formulation development of rabeprazole sodium buffered tablets

\section{Selection of buffers}

Water soluble buffers such as sodium bicarbonate and trisodium phosphate as well as water insoluble buffers as magnesium oxide, magnesium hydroxide and calcium carbonate were tested for their acid neutralizing capacity by adding a fixed dose of the buffer to a sample of artificial gastric juice. The basal stomach fluid contains $9.6 \mathrm{ml}$ of $0.1 \mathrm{~N}$ $\mathrm{HCl}$ and releases $0.5 \mathrm{ml}$ of $0.1 \mathrm{~N} \mathrm{HCl}$ per minute. The buffer was added to the basal simulated gastric fluid containing 9.6 $\mathrm{ml}$ of $0.1 \mathrm{~N} \mathrm{HCl}+210 \mathrm{ml}$ of water and titrated with excess acid $(0.1 \mathrm{~N} \mathrm{HCl})$ at the rate of $0.5 \mathrm{ml} /$ minute for a period of 1 hour (total volume $=250 \mathrm{ml}$ ). The buffer(s) which maintained a pH above 6.0 at the excess acid secretion were selected.

\section{Formulation of inner core tablet of the tablet-in-tablet by direct compression}

Rabeprazole sodium, sodium bicarbonate, mannitol, hydroxy propyl cellulose, crospovidone as shown in Table 1 were cosifted through 40 \# sieve on a vibratory sifter and collected. Iron oxide red was sifted through 100 \# sieve and collected. The sifted materials were loaded into the octagonal blender and mixed for 5 minutes. To the above mixed blend, colloidal silicon dioxide and magnesium stearate were added, blended for 5 minutes and compressed by using $7 \mathrm{~mm}$, round shaped flat- faced punches on a Rimek 16 station rotary compression machine with "B \& D" tooling.

Table 1 Physical characteristics of Inner core tablet

\begin{tabular}{|c|c|c|c|c|c|}
\hline \multirow{2}{*}{ S.No } & Ingredients & A 1 & A 2 & A 3 & A 4 \\
\cline { 3 - 5 } & & mg/Tab & mg/Tab & mg/Tab & mg/Tab \\
\hline 1. & Rabeprazole sodium & 20.00 & 20.00 & 20.00 & 20.00 \\
\hline 2. & Mannitol & 49.60 & 49.80 & 48.80 & 47.80 \\
\hline 3. & Hydroxy propyl cellulose & 4.00 & 3.00 & 2.00 & 2.00 \\
\hline 4. & Crospovidone & 4.00 & 4.00 & 5.00 & 6.00 \\
\hline 5. & Colloidal silicon dioxide & 0.50 & 1.00 & 1.50 & 1.50 \\
\hline 6. & Magnesium stearate & 1.20 & 1.50 & 2.00 & 2.00 \\
\hline 7. & Sodium bicarbonate & 20.00 & 20.00 & 20.00 & 20.00 \\
\hline 8. & Iron oxide red & 0.70 & 0.70 & 0.70 & 0.70 \\
\hline 9. & Total weight & 100.00 & 100.00 & 100.00 & 100.00 \\
\hline
\end{tabular}

\section{Formulation of outer layer buffer blend of the Tablet-in-} Tablet by Wet granulation

Sodium bicarbonate, magnesium oxide, mannitol were cosifted through 40 \# sieve. Hydroxyl propyl cellulose, crospovidone and aerosil were sifted individually through 40 \# sieve and collected separately. Magnesium stearate was sifted through 60 \# sieve. Binder solution was prepared by adding half quantity of hydroxy propyl cellulose to the weighed quantity of water $(350 \mathrm{ml} / 1000 \mathrm{tab})$ under constant stirring for 30 minutes. The sifted sodium bicarbonate, magnesium oxide, mannitol and half quantity of crospovidone were loaded into the Rapid Mixer Grinder bowl and mixed for 10 minutes by keeping impeller slow and chopper off. The binder solution was slowly added to the dry mix and the wet mass was kneaded with impeller and chopper both at fast speed and dried in hot air oven at $500 \mathrm{C}$ till the loss on drying of the dried granules become not more than $2 \%$ at 1050 C.Semidried granules were sifted through 20 \# sieve. To the dried granules the remaining half quantity of hydroxyl propyl cellulose and crospovidone were added and blended for 5 minutes in the octagonal blender. Colloidal silicon dioxide and magnesium stearate was added to the pre-lubricated blend and mixed for 5 minutes. 


\section{Formulation of Tablet-in-Tablet}

Formulation of tablet in tablet is shown in Table 2. Selected punches and dies (12 $\mathrm{mm}$ round $\mathrm{SC}$ ) were fixed to the compression machine. $350 \mathrm{mg}$ of buffer composition was filled into the die cavity of rotary press and core tablet was placed at the center and filled with remaining $350 \mathrm{mg}$ of buffer composition then finally compressed into a tablet.

Table 2 Physical characteristics of Tablet-in-Tablets

\begin{tabular}{|l|l|c|c|c|c|c|c|}
\hline \multirow{2}{*}{ S.No } & \multirow{2}{*}{ Ingredients } & F 1 & F 2 & F 3 & F 4 & F 5 & F 6 \\
\cline { 3 - 7 } & & $\mathrm{mg} / \mathrm{tab}$ & $\mathrm{mg} / \mathrm{tab}$ & $\mathrm{mg} / \mathrm{tab}$ & $\mathrm{mg} / \mathrm{tab}$ & $\mathrm{mg} / \mathrm{tab}$ & $\mathrm{mg} / \mathrm{tab}$ \\
\hline 1. & Inner core tablet & $\mathrm{A} \mathrm{4}$ & $\mathrm{A} \mathrm{4}$ & $\mathrm{A} \mathrm{4}$ & $\mathrm{A} \mathrm{4}$ & $\mathrm{A} \mathrm{4}$ & $\mathrm{A} \mathrm{4}$ \\
\hline 2. & Sodium bicarbonate & 300.00 & 300.00 & & & & \\
\hline 3. & Trisodium phosphate & & & 200.00 & 250.00 & 200.00 & 250.00 \\
\hline 4. & Magnesium oxide (heavy) & 250.00 & 300.00 & & & 250.00 & 300.00 \\
\hline 5. & Magnesium hydroxide & & 300.00 & 350.00 & & \\
\hline 6. & Mannitol & 83.50 & 22.00 & 113.50 & 6.50 & 152.00 & 52.00 \\
\hline 7. & Hydroxy propyl cellulose & 28.00 & 31.50 & 35.00 & 38.50 & 42.00 & 42.00 \\
\hline 8. & Crospovidone & 28.00 & 35.00 & 38.50 & 42.00 & 42.00 & 42.00 \\
\hline 9. & Colloidal silicon dioxide & 3.50 & 4.50 & 6.00 & 6.00 & 7.00 & 7.00 \\
\hline 10. & Magnesium stearate & 7.00 & 7.00 & 7.00 & 7.00 & 7.00 & 7.00 \\
\hline
\end{tabular}

\section{Evaluation of Tablets}

All the tablets were evaluated for different parameters as thickness, hardness, friability, uniformity of weight, disintegration time, drug content and in vitro dissolution study.

\section{Weight variation}

Randomly selected twenty tablets were weighed individually and together in a single pan balance. The average weight was noted and standard deviation calculated. The tablets pass the test if not more than two tablets fall outside the percentage limit and none of the tablet differs by more than double percentage limit.

$\mathrm{PD}=\left[\left(\mathrm{W}_{\text {avg }}-\mathrm{W}_{\text {initial }}\right) /\left(\mathrm{W}_{\text {avg }}\right)\right] \times 100$

Where, $\mathrm{PD}=$ Percentage deviation, $\mathrm{W}_{\text {avg }}=$ Average weight of tablet, $\mathrm{W}_{\text {initial }}=$ Individual weight of tablet

\section{Thickness}

The thickness and diameter of tablets was determined using Vernier Caliper. Twenty tablets from each batch were used and average values were calculated.

\section{Hardness}

The Monsanto hardness tester was used to determine the tablet hardness. The tablet was held between affixed and moving jaw. Scale was adjusted to zero; load was gradually increased until the tablet fractured. The value of the load at that point gives a measure of the hardness of the tablet. It is expressed in $\mathrm{kg} / \mathrm{cm} 2$. For each formulation, the hardness of six tablets was determined and average value was calculated.

\section{Drug content}

Tablets were crushed and the powder equivalent to $100 \mathrm{mg}$ of drug were accurately weighed and transferred to $50 \mathrm{ml}$ volumetric flask. To this flask, sufficient amount of distilled water was added to dissolve the tablets completely. Then, the volume of flask was made up to the mark with same solvent. From this solution, $1 \mathrm{ml}$ of the sample was pipetted out and transferred to $10 \mathrm{ml}$ volumetric flask. The volume in the second flask was made up to the mark with distilled water. From this $0.6 \mathrm{ml}, 0.8 \mathrm{ml}$ and $1 \mathrm{ml}$ samples were withdrawn and volume was made up to $10 \mathrm{ml}$ to maintain concentration within the beer's range. This final diluted solution was estimated UV spectrophotometrically at 275.43 nm.

\section{Friability}

Twenty tablets samples were weighed accurately and placed in friabilator (Roche Friabilator). After the given specification ( $4 \mathrm{~min}$ at $25 \mathrm{rpm}$ ), loose dust was removed from the tablets. Finally tablets were weighed. The loss in weight indicates the ability of the tablets to withstand this type of wear. The $\%$ friability was then calculated by:

$\%$ Friability $=($ Loss in weight $/$ Initial weight $) \times 100$

\section{Disintegration test}

Disintegration is evaluated to ensure that the drug substance is fully available for dissolution and absorption from the gastrointestinal tract. Disintegration test was carried out using tablet disintegration test apparatus (EI Instrument, India) using $0.1 \mathrm{~N} \mathrm{HCl}$ without disk at room temperature $(37 \pm 2 \mathrm{C})$.

\section{Acid neutralizing capacity}

Accurately weighed quantity, equivalent to the minimum labeled dosage of tablet in tablet was transferred to a $250 \mathrm{ml}$ beaker, to this $10 \mathrm{ml}$ of water was added and swirled gently. The walls of the beaker were washed with $60 \mathrm{ml}$ of water and mixed don the magnetic stirrer for 1 minute. $30 \mathrm{ml}$ of $1 \mathrm{~N}$ $\mathrm{HCl}$ was pipette out into the test preparation and stirred continuously for 15 minutes and excess hydrochloric acid was titrated with $0.5 \mathrm{~N} \mathrm{NaOH}$ to attain a stable $\mathrm{pH}$ of 3.5. The number of $\mathrm{mEq}$ of acid consumed was calculated by the formula (USP-NF 26).

\section{Differential scanning calorimeter (DSC)}

The physical state of drug was analyzed by DSC. The thermograms of Rabeprazole and with different polymers were obtained at a scanning rate of $10^{\circ} \mathrm{C} / \mathrm{min}$ conducted over a temperature range of $25-350^{\circ} \mathrm{C}$.

\section{In vitro drug release studies}

In vitro drug release studies were carried out in $900 \mathrm{ml}$ of $0.1 \mathrm{M} \mathrm{HCl}$ for the first $2 \mathrm{~h}$ using a USP XXII type 1 dissolution apparatus (Electrolab TDT-08L) at $60 \mathrm{rpm}$ and $37 \pm 0.5^{\circ} \mathrm{C}$. At predetermined time intervals during the dissolution test, samples $(10 \mathrm{ml})$ were withdrawn for assay and replaced with equivalent volume of fresh medium to maintain conditions. All dissolution studies were performed in triplicate. The samples were filtered, diluted appropriately and then analyzed spectrophotometrically (Systronics, India) for Rabeprazole at $275.43 \mathrm{~nm}$. 


\section{Kinetic analysis of dissolution data}

The release data were fitted to five kinetic models, viz, zeroorder, first-order, Higuchi and Korsmeyer-Peppas to determine drug release mechanism.

\section{Stability studies of the tablets}

For the prepared tablets, the stability studies were carried out at intermediate and accelerated conditions for a period of one month. At the end of study period the samples was analyzed by appropriate methods to determine the stability of formulation.

\section{RESULT AND DISCUSSION}

The melting point of rabeprazole was found to be $140-141{ }^{\circ} \mathrm{C}$. Solution was scanned under UV-Vis Spectrophotometer and $\lambda$ max was determined. It was found to be $275.43 \mathrm{~nm}$ Fig.1. Partition coefficient of rabeprazole 0.1M HCL was found to be 1.16. From the spectra of rabeprazole, physical mixture of drug and selected ingredients was observed that all characteristic peaks of rabeprazole were present in the combination spectrum, thus indicating compatibility between drug and selected ingredients. FTIR spectra were shown in Fig. 2 and 3. DSC Thermo grams of rebeprazole sodium and with HPMC were obtained showed that no significant differences were observed Fig. 4 and 5. Different buffering agents and alkaline agents (Sodium bicarbonate, Trisodium phosphate, Magnesium oxide (heavy), Magnesium hydroxide) are used for neutralizing pH of SGF and there combination also tried for same shown in Table 3 . The powder blend of the all designed formulations containing rebeprazole sodium were evaluated for parameters like angle of repose was found to be $39.13,36.24,33.87$ and 32.11 , Bulk density was found to be $0.789,0.784,0.699$ and $0.776 \mathrm{~g} / \mathrm{cm}^{3}$, tapped density $1.067 \quad 1.078 \quad 1.666$

$1.079 \mathrm{~g} / \mathrm{cm} 3$, Hausner's ratio1.34, 1.32, 1.35 and 1.31 Carr's index 26.89, 26.60, 26.45 and 26.75were found for A1, A2, A3 and A4 formulation respectively and reported in Table 4. Physical characteristics of inner core tablet of rabeprazole were given in Table 5 . The formulated tablets were evaluated for their organoleptic characters. The tablets are round shaped, biconvex, round in shape and white in colour. All the tablets showed elegance in appearance. Thickness of the tablets was found to be in the range of $5.3 \pm 0.03 \mathrm{~mm}$ to $5.5 \pm 0.03 \mathrm{~mm}$. The results showed that the thickness of all formulated tablets was found to be uniform. The hardness of the tablets was measured by Monsonto hardness tester. The hardness of all the formulations was found to be in the range of 5 to $9 \mathrm{~kg} / \mathrm{cm}^{2}$. It indicates all the tablets have adequate mechanical strength. Twenty tablets of each formulation were selected for weight variation test. The accepted percentage deviation was \pm 7.5 for 130 -324mg weight tablets. The results showed that weight variation was ranging from $798 \pm 5$ to $802 \pm 5 \mathrm{mg}$. It was within the I.P. limit and all the tablets passed the weight variation test. Friability test was carried out by Roche friabilitor. The maximum weight loss should be not more than $1 \%$. The maximum and minimum friability values among 6 formulations were found to be in the range of 0.36 to 1.08 . Hence all the tablets passed the friability test. The disintegration time of core tablets were found in the range between 42 to110sec. The results revealed that the disintegration time was within the acceptable limits. The assay of Rabeprazole sodium tablets were found in the range between 98.04 and 101.20. The acceptable limit of Rabeprazole sodium content as per I.P. is 90 to $110 \%$. The results revealed that the assay of rabeprazole sodium was within the acceptable limits. In the present study, pH of $\mathrm{F} 6$ batch was found to be optimum and disintegration time is 42 sec. In-vitro drug release studies were done for the selected formulations from each batch. The drug release was found to show maximum drug release in case of F6 with $99.3 \%$ in 60 minutes as shown in table 6 and Fig 6. All formulations showed good acid neutrizing capacity in the range of 16.57 to 24.72 m.Eq Table 7. Stability testing was conducted to know how the quality of a drug substance or drug product varies with time under the influence of a variety of environmental factors. In the present stability study of the optimized batch, all the results were found to be satisfactory and within limits. There were no significant changes after the period of 1 month study Table 8.

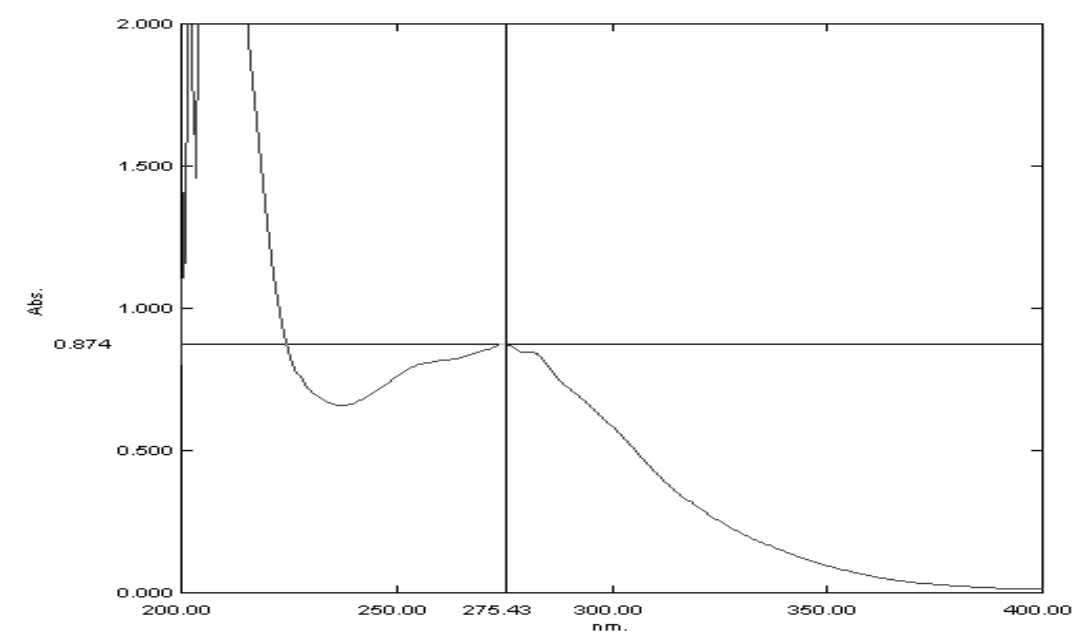

Figure1 UV spectra of Rabeprazole 


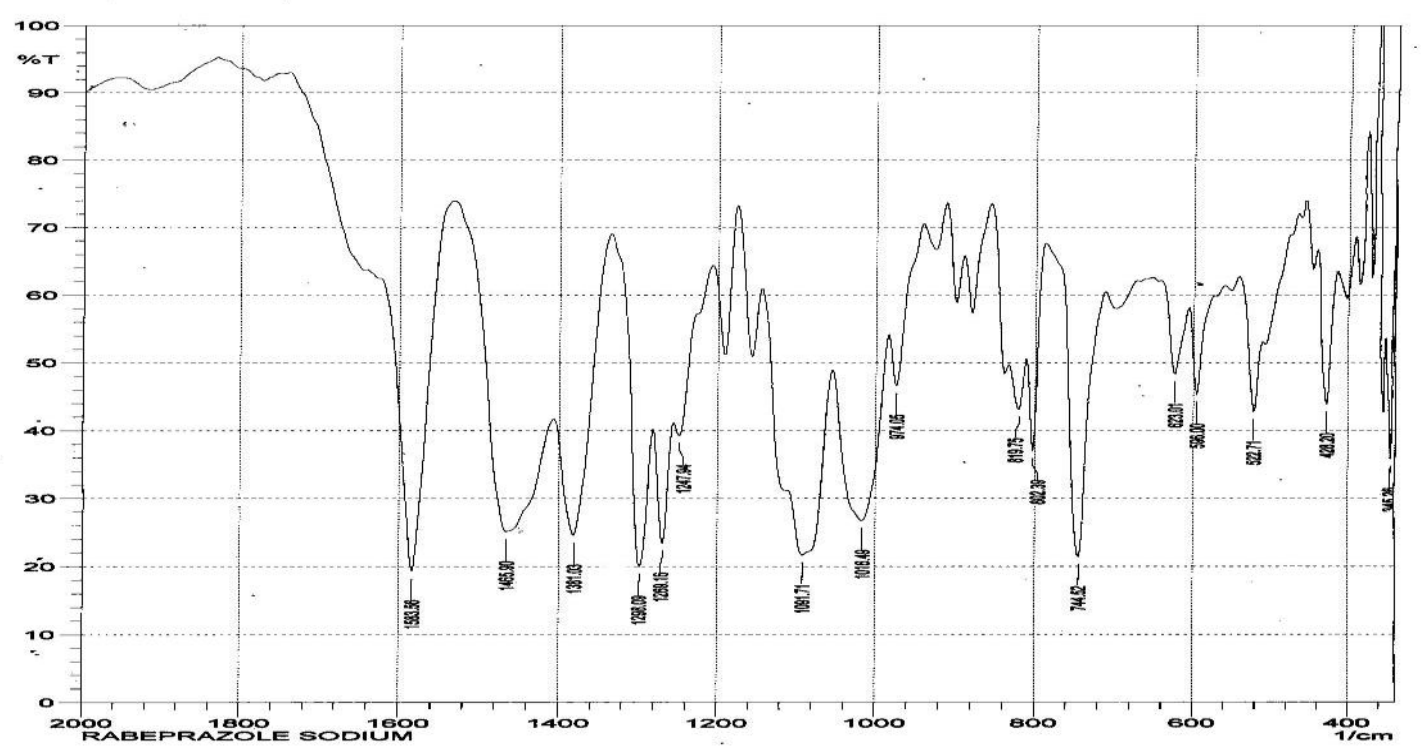

Figure 2FTIR spectra of Rabeprazole sodium

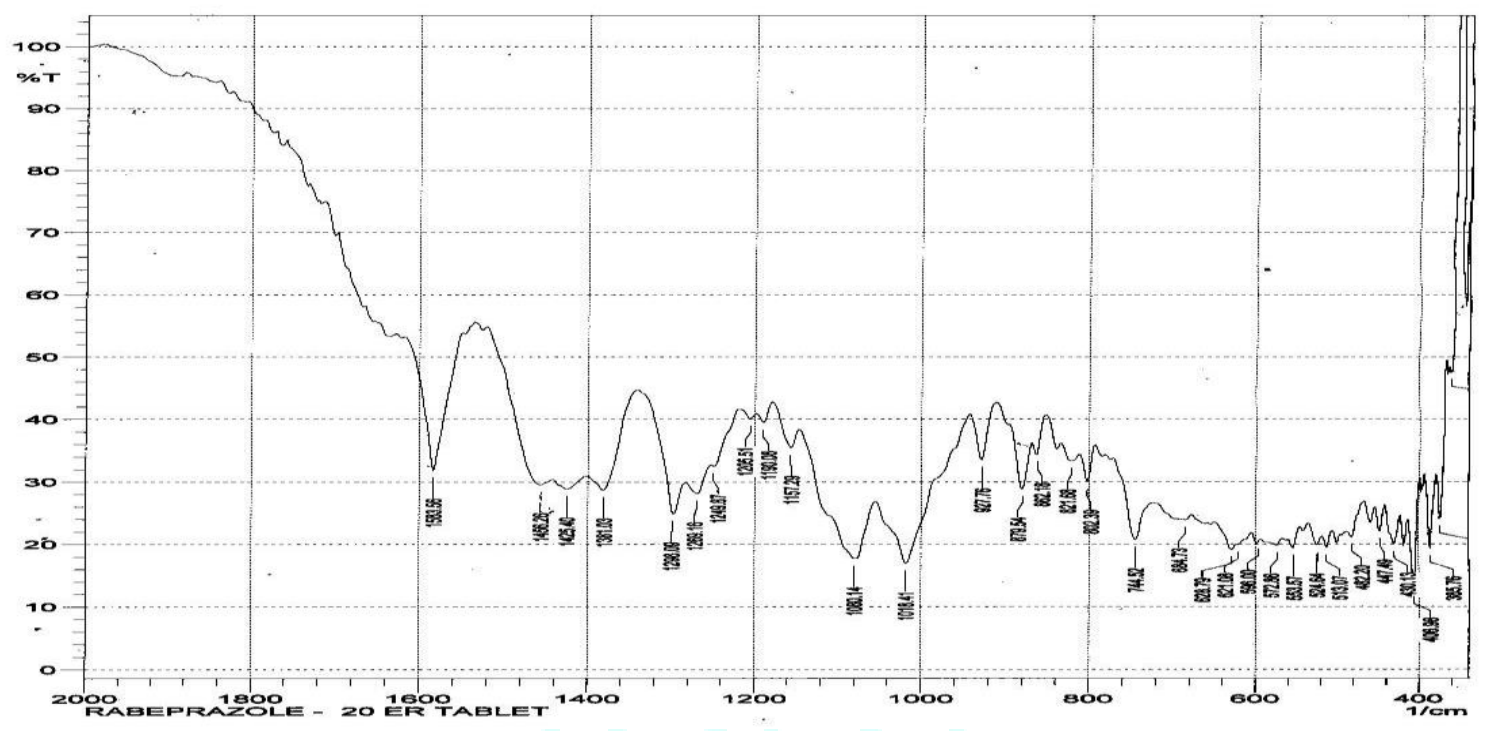

Figure 3 FTIR spectra of Rabeprazole sodium tablet

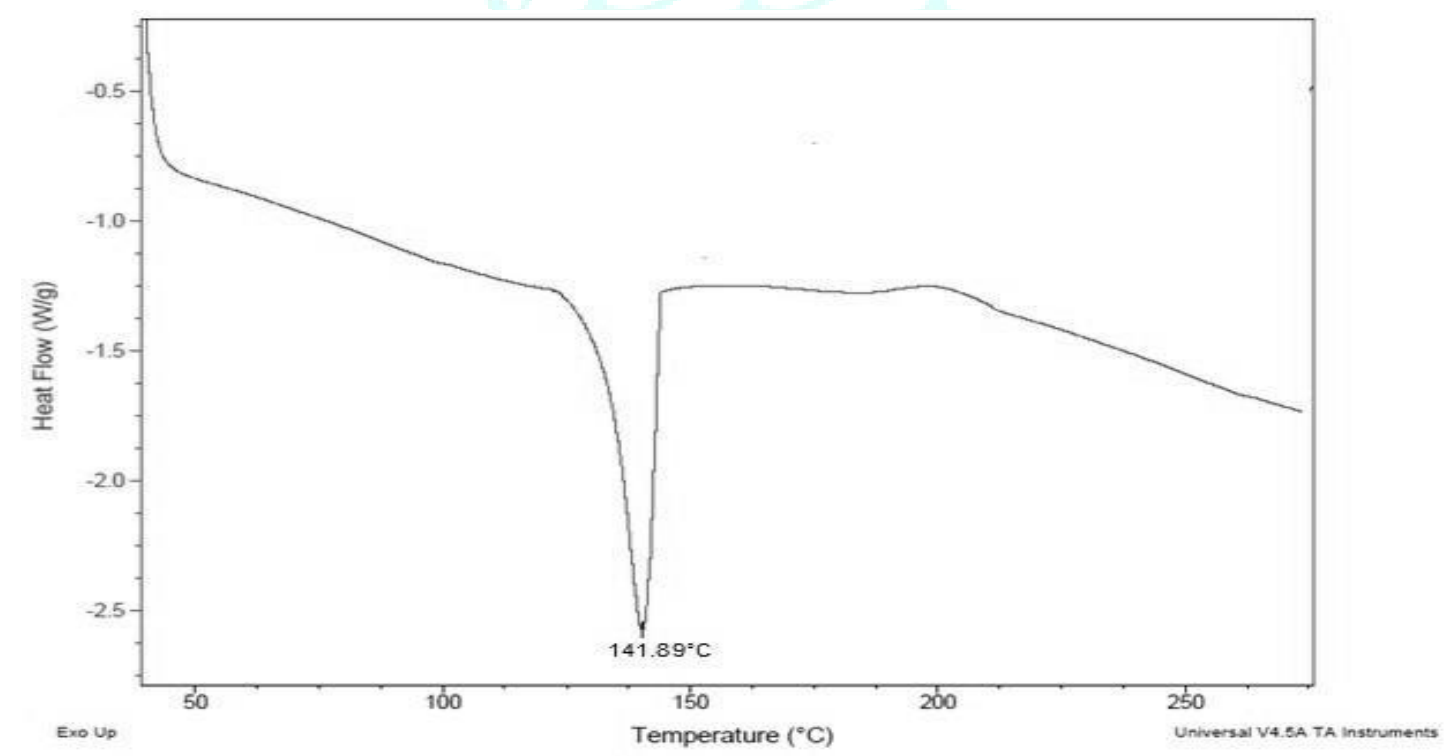

Figure 4 DSC of Rabeprazole sodium 


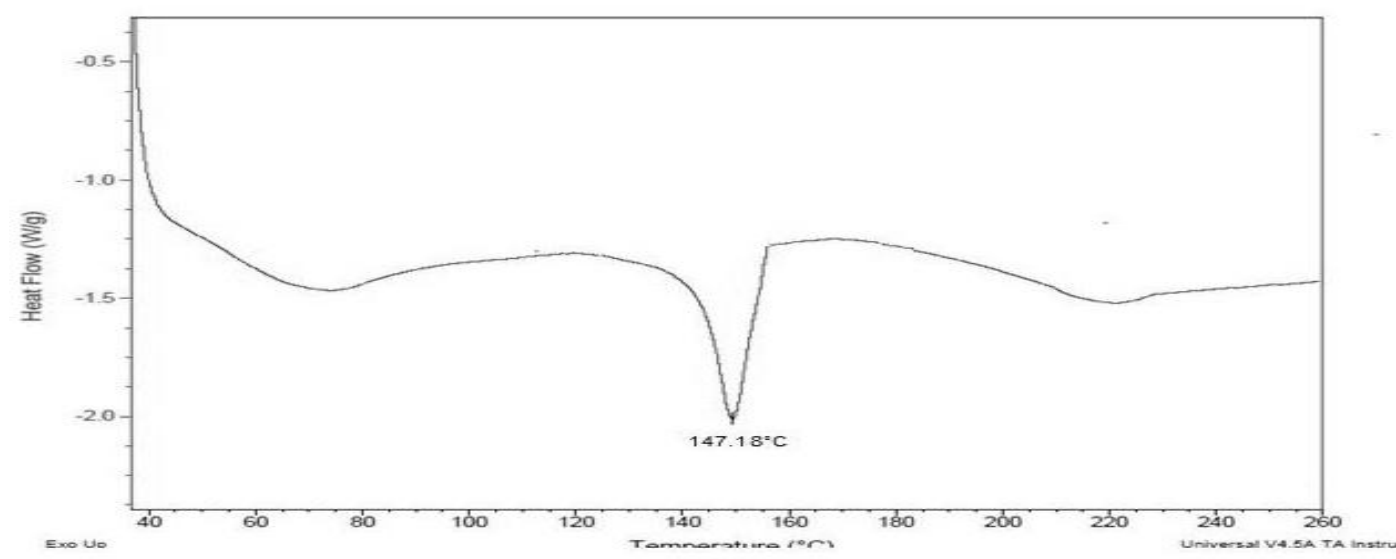

Figure 5 DSC of formulation with HPMC

Table 3 Buffering capacity of different buffers

\begin{tabular}{|l|l|l|l|l|l|l|}
\hline Name of Buffering agent & \multicolumn{7}{|c|}{ Buffering agent conc. } \\
\hline Sodium bicarbonate & 300.00 & 300.00 & & & & \\
\hline Trisodium phosphate & & & 200.00 & 250.00 & 200.00 & 250.00 \\
\hline Magnesium oxide (heavy) & 250.00 & 300.00 & & & 250.00 & 300.00 \\
\hline Magnesium hydroxide & & & 300.00 & 350.00 & & \\
\hline pH Achieve & 5.73 & 6.51 & 5.42 & 5.95 & 3.14 & 4.98 \\
\hline
\end{tabular}

Table 4 Evaluation of powder blend

\begin{tabular}{|l|l|l|l|l|}
\hline \multirow{2}{*}{\multicolumn{1}{|c|}{ Parameters }} & \multicolumn{4}{c|}{ Formulations } \\
\cline { 2 - 5 } & \multicolumn{1}{|c|}{ A 1 } & \multicolumn{1}{c|}{ A 2 3} & \multicolumn{1}{c|}{ A 4 } \\
\hline BulkDensity $\left(\mathrm{g} / \mathrm{cm}^{3}\right)$ & 0.789 & 0.784 & 0.699 & 0.776 \\
\hline TappedDensity $\left(\mathrm{g} / \mathrm{cm}^{3}\right)$ & 1.067 & 1.078 & 1.666 & 1.079 \\
\hline AngleofRepose( $\theta)$ & 39.13 & 36.24 & 33.87 & 32.11 \\
\hline Carrsindex(\%) & 26.89 & 26.60 & 26.45 & 26.75 \\
\hline Hausnersratio(HR) & 1.34 & 1.32 & 1.35 & 1.31 \\
\hline
\end{tabular}

Table 5 Physical characteristics of Inner core tablet of Rabeprazole

\begin{tabular}{|c|c|c|c|c|c|}
\hline \multirow{2}{*}{ S.No } & Parameter & \multicolumn{4}{|c|}{ Formulations } \\
\cline { 3 - 6 } & Appearance & A 1 & A 2 & A 3 & A 4 \\
\hline 1. & & $\begin{array}{c}\text { Brick red colour, } \\
\text { round shaped tablets }\end{array}$ & $\begin{array}{c}\text { Brick red colour, } \\
\text { round shaped tablets }\end{array}$ & $\begin{array}{c}\text { Brick red colour, } \\
\text { round shaped tablets }\end{array}$ & $\begin{array}{c}\text { Brick red colour, } \\
\text { round shaped tablets }\end{array}$ \\
\hline 2. & Weight variation (mg) & $101 \pm 5.0$ & $98 \pm 5.0$ & $102 \pm 5.0$ & $99 \pm 5.0$ \\
\hline 3. & Thickness(mm) & $2.2 \pm 0.3$ & $2.1 \pm 0.3$ & $2.2 \pm 0.3$ & $2.0 \pm 0.3$ \\
\hline 4. & Hardness ( kg/cm2) & $3.0-4.0$ & $2.0-3.0$ & $2.0-3.0$ & $2.0-3.0$ \\
\hline 5. & Friability (\%) & 0.04 & 0.07 & 0.05 & 0.06 \\
\hline 6. & Disintegration(Sec.) & 30 & 42 & 45 & 25 \\
\hline
\end{tabular}

* All the values are expressed as mean \pm SD; $n=3$.

Table 6 Physical characteristics of buffered tablets of Rabeprazole

\begin{tabular}{|c|c|c|c|c|c|c|c|}
\hline \multirow[t]{2}{*}{ S.No } & \multirow[t]{2}{*}{ Parameter } & \multicolumn{6}{|c|}{ Formulations } \\
\hline & & F 1 & F 2 & F 3 & F 4 & F 5 & F 6 \\
\hline 1 & Appearance & $\begin{array}{l}\text { White colour, } \\
\text { round shaped, } \\
\text { biconvex }\end{array}$ & $\begin{array}{l}\text { White colour, } \\
\text { round shaped, } \\
\text { biconvex }\end{array}$ & $\begin{array}{l}\text { White colour, } \\
\text { round shaped, } \\
\text { biconvex }\end{array}$ & $\begin{array}{l}\text { White colour, } \\
\text { round shaped, } \\
\text { biconvex }\end{array}$ & $\begin{array}{l}\text { White colour, } \\
\text { round shaped, } \\
\text { biconvex }\end{array}$ & $\begin{array}{l}\text { White colour, } \\
\text { round shaped, } \\
\text { biconvex }\end{array}$ \\
\hline 2 & $\begin{array}{l}\text { Weight variation } \\
\text { (mg) }\end{array}$ & $802 \pm 5.0$ & $799 \pm 5.0$ & $804 \pm 5.0$ & $803 \pm 5.0$ & $798 \pm 5.0$ & $801 \pm 5.0$ \\
\hline 3 & Thickness (mm) & $5.5 \pm 0.3$ & $5.3 \pm 0.3$ & $5.5 \pm 0.3$ & $5.4 \pm 0.3$ & $5.3 \pm 0.3$ & $5.4 \pm 0.3$ \\
\hline 4 & $\begin{array}{l}\text { Hardness } \\
(\mathrm{kg} / \mathrm{cm} 2)\end{array}$ & $5.0-6.0$ & $8.0-9.0$ & $7.0-8.0$ & $8.0-9.0$ & $8.0-9.0$ & $8.0-9.0$ \\
\hline 5 & Friability (\%) & 1.08 & 0.82 & 0.80 & 0.63 & 0.37 & 0.36 \\
\hline 6 & $\begin{array}{c}\text { Disintegration } \\
\text { (Sec.) }\end{array}$ & 110 & 60 & 70 & 45 & 48 & 42 \\
\hline 7 & Drug content (\%) & 98.04 & 100.07 & 99.35 & 101.20 & 98.92 & 99.02 \\
\hline
\end{tabular}

* All the values are expressed as mean \pm SD; $n=3$ 


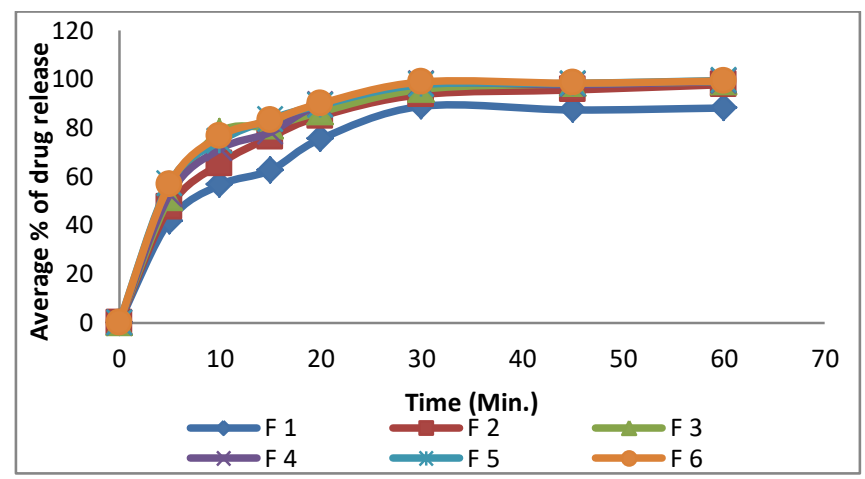

Table 7 Test for acid neutralizing capacity of formulations

\begin{tabular}{|c|c|c|}
\hline S. No. & Formulation & $\begin{array}{c}\text { Acid Neutralizing } \\
\text { Capacity (m.Eq.) }\end{array}$ \\
\hline 1. & F1 & 18.51 \\
\hline 2. & F2 & 22.16 \\
\hline 3. & F3 & 16.57 \\
\hline 4. & F4 & 18.95 \\
\hline 5. & F5 & 21.66 \\
\hline 6. & F6 & 24.72 \\
\hline
\end{tabular}

Figure 6 Percent drug release study in simulated gastric fluid

Table 8Stability studies of tablets

\begin{tabular}{|c|c|c|c|}
\hline \multirow[t]{2}{*}{ Test name } & \multirow[t]{2}{*}{ Initial } & \multicolumn{2}{|c|}{1 Month } \\
\hline & & $30^{\circ} \mathrm{C} / 65 \% \mathrm{RH}$ & $40^{\circ} \mathrm{C} / 75 \%$ RH \\
\hline Description & \multicolumn{3}{|c|}{ Yellow colour, round shaped, biconvex film coated tablets } \\
\hline Average weight (mg) & 825.06 & 825.33 & 825.51 \\
\hline Thickness (mg) & 5.58 & 5.58 & 5.58 \\
\hline Hardness $(\mathrm{kg} / \mathrm{cm})$ & $8.0-9.0$ & $8.0-9.0$ & $8.0-9.0$ \\
\hline Disintegration (min) & $4.0-5.0$ & $4.0-5.0$ & $4.0-5.0$ \\
\hline Assay (\%) & 99.07 & 99.03 & 99.08 \\
\hline Dissolution Time (min) & \multicolumn{3}{|c|}{ \% Drug Release } \\
\hline 5 & 66.8 & 54.5 & 57.3 \\
\hline 10 & 76.6 & 79.3 & 77.1 \\
\hline 15 & 83.1 & 85.2 & 83.8 \\
\hline 20 & 90.1 & 90.6 & 89.9 \\
\hline 30 & 98.9 & 99.1 & 98.5 \\
\hline 45 & 99.3 & 99.4 & 99.2 \\
\hline 60 & 99.5 & 99.4 & 99.5 \\
\hline
\end{tabular}

\section{CONCLUSION}

In the present work, an attempt was made to develop buffered tablet of rabeprazole sodium by direct compression and wet granulation method using sodium carbonate, sodium bicarbonate as a buffering agent, Crosspovidone as Super-disintegrants and mannitol as a diluents. Six formulations (F1-F6) were prepared, the optimum concentration were identified based on the disintegration time and in vitro drug release results. In the present study, $\mathrm{pH}$ of $\mathrm{F} 6$ batch was found to be optimum and disintegration time is $42 \mathrm{sec}$. The drug release was found to show maximum drug release in case of $\mathrm{F} 6$ with $99.3 \%$ in 60 minutes. The results demonstrated the effective use of buffered tablet of rabeprazole and as an ideal drug release formulation for treatment of peptic ulcers and different acidic conditions.

\section{ACKNOWLEDGEMENT}

The authors are very much thankful to the Pinnacle Biomedical Research Institute (PBRI), Bhopal, (M.P), 462003 India for providing facility to carrying out this research work.

\section{REFERENCES}

1. Arora S, Aneja DK, Kumar M, Prakash O. Correlation studies between dissolution and thermal rate constants of rabeprazole sodium drug and their tablets. Der Pharmacia Lettre 2011; 3(3):272-279.

2. Shafee MM, Abdulgani TM, Shaikh SZ, Kondaguli AV. Immediate release composition of acid labile drugs. United States Patent application Publication No US/2011/ 0171295A1; 1-9.

3. Bigoniya P, Shukla A, Gotiya CV. Comparative anti-ulcerogenic study of pantoprazole formulation with and without sodium bicarbonate buffer on pyloric ligated rat. J Pharmacol Pharmacothera 2011; 2(3): 179-189.

4. Taneja, Rajneesh, Gurnee, Gupta P, Gurnee IL. Pharmaceutical composition of A non-enteric coated proton pump inhibitor with a carbonate salt and bicarbonate salt combination European patent no. EP 1353624 B 2 to 10.

5. Rajneesh, Taneja, Gupta P. Pharmaceutical composition of a non-enteric coated proton pump inhibitor with a carbonate salt and bicarbonate salt combination United States Patent application Publication No US/2012/0142737: 1-5.

6. Guo J, Fang X, Li S, He H, Tang X. Sodium bicarbonate coated omeprazole immediate release pellets to improve bioavailability improving stability in gastric acid. Asian Pharma Sci 2011; 1-3.

7. Warren Hall et al. Novel formulation of proton pump inhibitors and method of using these formulations. United States patent no. US2009/0092658A1.

8. Small RE. Advances in proton pump inhibitor therapy: an immediate-release formulation of Omeprazole. Drug Forecast 2005; 30(12): 698-713. 